\title{
TBL, Self-assessment, and Use of ICT: A Methodological Option to Benefit the English Learning Process in a Colombian University
}

\author{
María Constanza Rodríguez \\ Language Department, Politécnico Grancolombiano, Colombia \\ Lady Johanna Ramírez \\ Language Department, Politécnico Grancolombiano, Colombia \\ Javier Mauricio Camargo \\ Language Department, Politécnico Grancolombiano, Colombia
}

\begin{abstract}
For more than 10 years, English teaching and learning approaches at Politecnico Grancolombiano were based on traditional methodologies with noticeable prevalence of deductive learning and summative assessment. In 2017, we surveyed students and teachers to analyze this panorama, and more than 500 responses shed light on the lack of motivation most of them had in their English learning and teaching processes. As a result, through a qualitative research project, we implemented the task-based teaching and learning approach in our English classes, featuring formative assessment, the use of information and communication technologies, and encouraging self-reflection moments for students to raise awareness of their learning process. The objective of this project was to identify the real benefits of these methodological changes in our programs, and to ensure triangulation, we used different data collection instruments such as journals, artifacts and surveys. It was found that task-based lessons offer students innovative, creative and real opportunities to learn English in and out of class. As well, students' motivation and awareness of their learning process increased due to formative assessment routines. As for teachers, it can be concluded that these methodological innovations helped them plan more dynamic lessons and evidence students' progress. Regarding Information and Communication Technologies (ICT), it was evident that it played an important role in teachers' and students' engagement. However, it revealed that it was necessary to strengthen technological skills and to guarantee the conditions to implement it.
\end{abstract}

Index Terms - task-based learning, self-assessment, E-portfolios, ICT, awareness and motivation

\section{INTRODUCTION}

Traditionally, Colombia has worked consistently to find ways to improve the quality of EFL teaching and learning. Consequently, new approaches have been implemented in order to deal with the challenges posed by the demands of the local policy, which requires university graduate students to reach level B2 according to the Common European Framework of Reference for Languages (CEFRL). In 2014, the Ministry of Education implemented the National Program of English, Colombia Very Well, which seeks to improve teaching and learning of English by 2025. This is a long-term initiative sponsored by different entities that commit to the development of EFL skills in the country, which was conceived based on the needs of our education system.

As a result of this initiative and implicit demand from the government and, in general, from the globalized world, Colombian higher education institutions have been trying to meet these expectations by following communicative teaching approaches for the acquisition and learning of this foreign language.

Even though at Politécnico Grancolombiano English syllabi were for the last 15 years designed within the communicative approach, its rationale was not fully embraced. In general terms, classes were not learner-centered, learners' specific contexts were not considered, and the materials used in the classes were not always authentic. Since new generations demand changes and challenges, our Language Department decided to respond to these demands and to include students' views in those changes. For that purpose, a survey was applied to 500 students who, through this tool, manifested they wanted to be involved in their process, and they considered the topics suggested in the textbooks were sometimes meaningless and the evaluation methods unconnected.

Research on methodologies that allow students to have an active role throughout their process suggested that TaskBased Learning (TBL), self-assessment and a greater use of ICT would empower them with learning and evaluation strategies. TBL mainly implies three important elements: inductive learning, a scaffolded process and the development of significant reality-based tasks in which grammar is not considered the starting point but the means to reach a communicative outcome. In connection with these characteristics, self-assessment plays a vital role as it promotes 
students' reflection not only on the language students naturally practice along the tasks, but also, on the planning of actions intended to accomplish their learning and communicative goals. In this scenario, ICT turns out to be highly pertinent since it allows teachers and learners to explore new ways to use technology and access authentic and contextualized materials and information. This, in turn, helps the institution be at the forefront of technology advances for educational purposes.

\section{LITERATURE REVIEW}

\section{A. Self-assessment}

Self-assessment has been related to motivational aspects that, based on educational psychology research, are necessary to ensure lifelong learning. Panadero, Jonsson, \& Botella (2017) concluded that self-assessment is directly intertwined with self-regulation and self-efficacy and, thus, with the drive students need to achieve results. However, the acquisition of self-assessment strategies is gradual and requires a thorough training of all the actors involved. This complete development process includes "(1) determining the performance criteria, (2) self-directed feedback seeking and (3) self-reflection" (Yan \& Brown, 2017) and must be systematically accounted for in such a way that it can be easily retrieved. In this respect, e-portfolios have proved to engage students into the practice of evaluating their process. Bertolotti \& Beseghi (2016) validated that the European Language Portfolio (ELP) fosters reflection, autonomy, peer interaction, and goal-setting - skills that, though complex to acquire, result in scaffolded and evolved learning processes

\section{B. Task-based Learning}

The task-based learning approach has been recognized and accepted worldwide in a great variety of contexts. Regarding higher education, Lau (2009) implemented a TBL program with university students, and the results of her research project showed a steady increase of students' intrinsic and extrinsic motivation to learn English as a foreign language. They regarded their learning process as something fun and interesting since tasks were relevant to their needs, interests and life experiences. Additionally, the TBL approach had a positive impact on students' awareness to use the language more effectively when speaking. Similarly, research conducted by Tang, Chiou \& Jarsaillon (2015) in a Taiwanese university showed that the TBL approach was motivational and useful for language acquisition since the participants of their study made significant progress in terms of sentence structure, sophisticated vocabulary, stress, intonation and fluency during impromptu oral presentations. Regarding standardized tests, the researchers concluded that students improved considerably their reading skills due to the use of texts as the main input of the oral tasks developed in class.

\section{Information and Communication Technologies}

ICT has broadly been studied for they allow learners to communicate, interact and access information through a wide array of online tools, learning materials and social networks. Some research articles have talked about the results obtained after incorporating ICT in the process of learning and teaching English as a foreign language. These studies have shown technology is crucial since it promotes students' motivation to learn and fosters innovative learning opportunities. Abarca (2015), in his study conducted in Costa Rica, found that ICT tools make classes more interesting, dynamic, creative and significant for learners. Besides, it revealed that students' high motivation caused teachers to be even more motivated than usual. Another study, carried out in Argentina (Morchio, 2014), revealed that most of the students agreed that technology facilitated their English learning, and that using social networks engaged them in outof-the-ordinary real-life situations. Similarly, Rahmanita \& Cahyono (2018) referred that undergraduate students improved their motivation and ability to write in English as long as teachers guaranteed all the necessary conditions to access and use technology effectively.

\section{METHOD OF STUDY}

We decided to carry out our project following the action research cycle as it allows researchers to systematically reflect upon a situation within its social context. Moreover, as Elliot (1990) explained it, this is the most suitable research methodology to approach and adapt educational contexts, through continuous reflection processes. In our case, this pondering was closely linked to the assessment of the different elements of the project. In fact, the main interest of the Language Department team was to work collaboratively and to use the findings of this research to inform and improve teaching practices. In order to obtain a wider understanding of all the aspects of the project, we integrated elements of quantitative and qualitative research approaches.

The principal objective of the project was to determine the impact of the implementation of TBL, self-assessment and ICT in the learning process of English Foreign Language students at Politécnico Grancolombiano.

The participants of this research project were 341 students of English as a foreign language at this institution. They belonged to different study programs and were enrolled in one of the English courses offered by the university in the second semester of 2018. These courses were arranged in four levels which aim at reaching level B1 according to the CEFRL. In addition, all the English teachers of the Language Department participated along the implementation of this 
project by piloting the programs, keeping a record of their experience, and answering the final survey on their perceptions.

Due to the qualitative nature of this research project, observations and journals were used because they allow researchers to capture relevant aspects, events and reflections of a given topic of interest (Fetterman, 1989). Among the non-observational techniques, artifacts were analyzed since they are tangible evidence of students' performance and attitudes (Kalmback and Carr, 2014). These instruments were useful to gather information because they permitted both students and researchers to keep track of experiences that resulted from actual learning activities. In addition, research surveys results were obtained from students and teachers that were asked to share their perceptions about the need, use and effect of the implementation of TBL, ICT and self-assessment.

\section{FINDINGS}

\section{A. Self-assessment}

Over the course of the pilot project, all teachers observed that, though gradually, students developed to some extent self-assessment skills that eventually empowered them and increased their self-awareness and subsequent motivation. In fact, it was validated that the ability to self-assess that students acquire has a direct link with commitment and engagement with learning, as Brown and Harris claimed (2013). In the final survey, applied to 341 students, $32 \%$ confirmed they were naturally motivated with the fact they could be involved in their assessment, from the beginning. However, 39\% acknowledged they only started feeling motivated as the course progressed and they realized the importance of being key players of their process. This could also be observed in the content of their portfolios, which progressively became richer in terms of the strategies they chose, their reflections about their use and benefits, and the samples of their work. Figures 1, 2 and 3 are examples of these three parts of the portfolio.

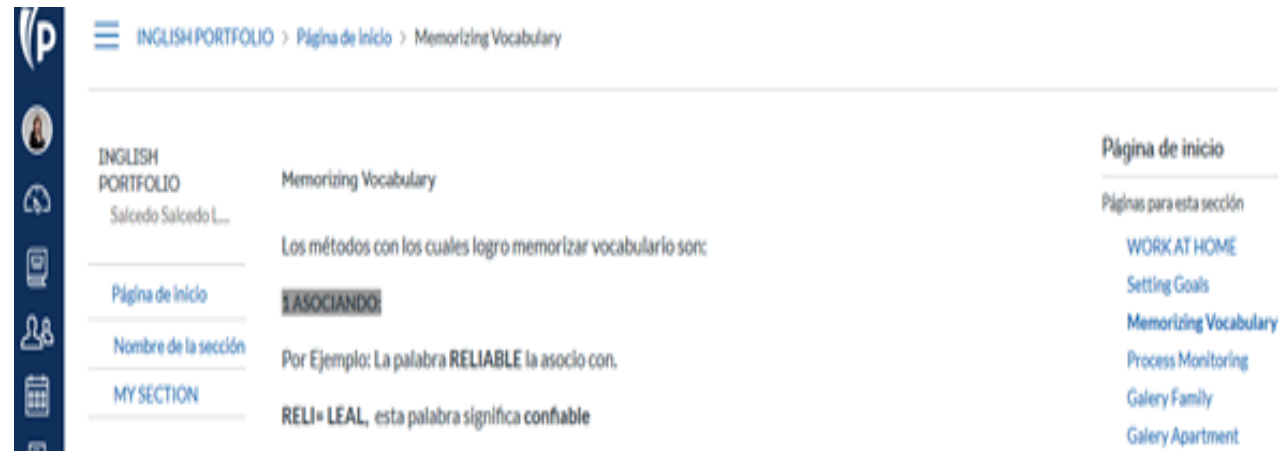

Figure 1. Student's choice and use of a strategy to memorize vocabulary evidences their development of metacognitive awareness.

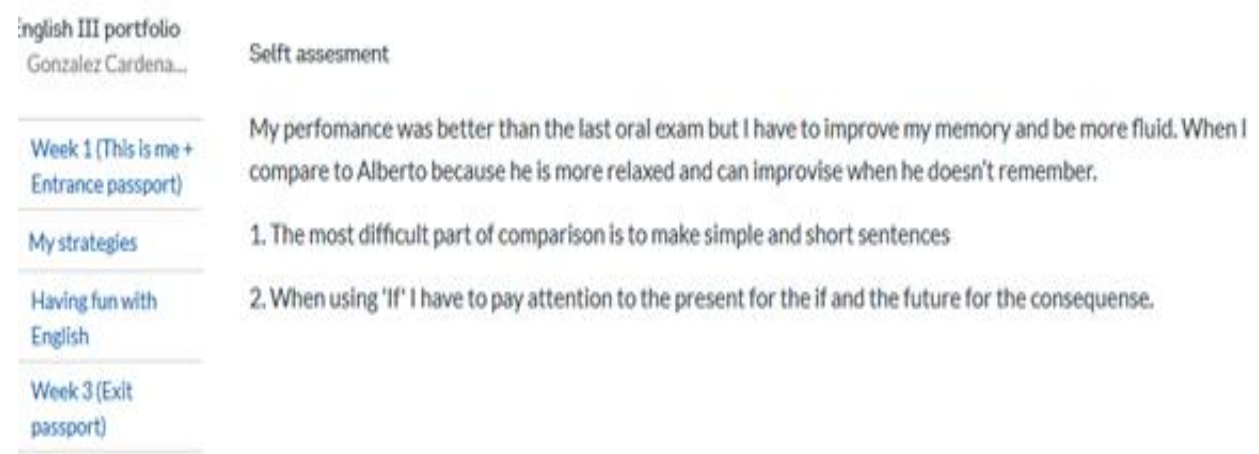

Figure 2. Student's reflection shows criticism to self-assess their learning process 


\section{The "Black Beast" in the oceans}
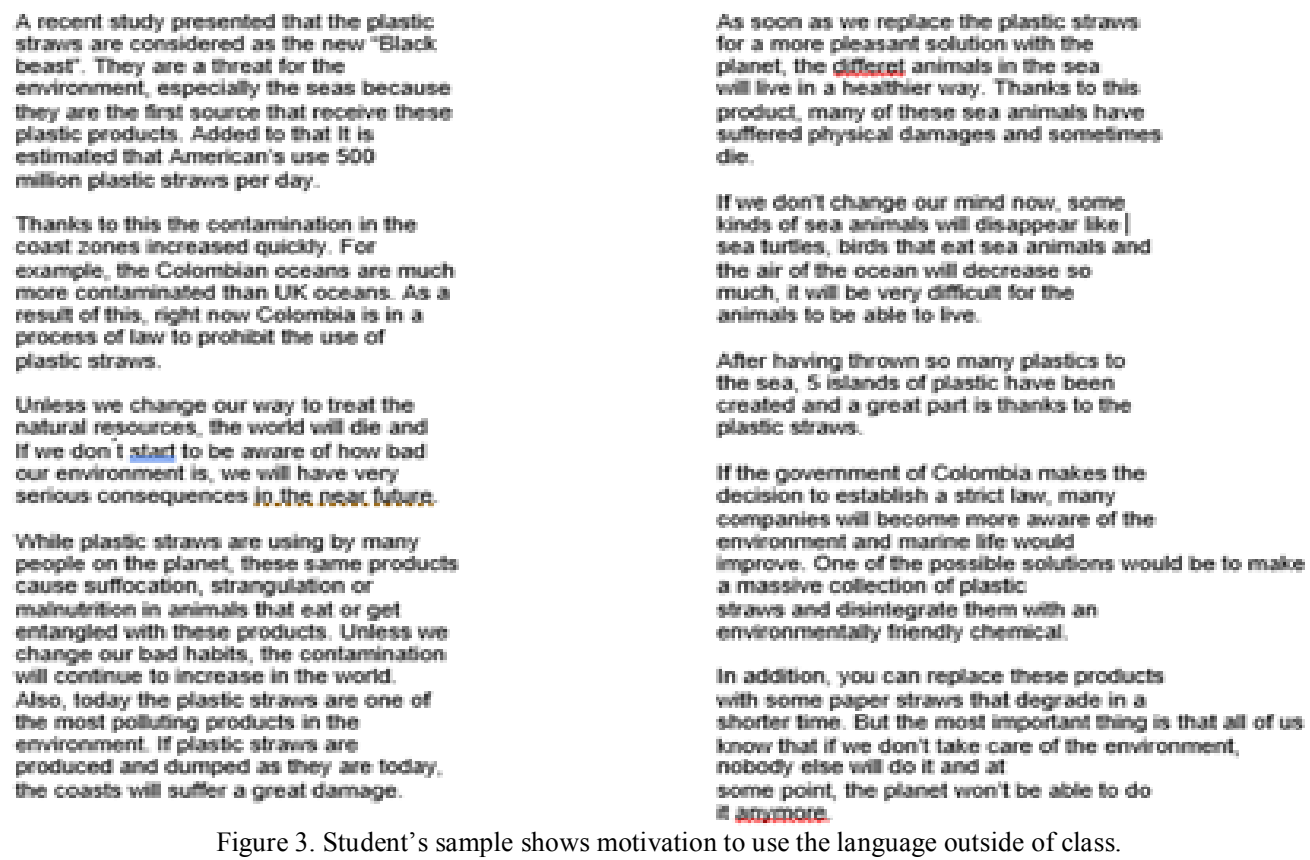

Figure 3. Student's sample shows motivation to use the language outside of class.

Parallel to this gradual engagement, self-awareness emerged in the scene. $70 \%$ of students explained they were motivated because the regular self-assessment practices helped them be aware of their process, their strengths and their flaws. They appreciated the fact that it was a gradual process, and the more they were exposed to these reflections, the more they understood the complexity of learning a language. Some of them highlighted the fact that pondering upon their learning process made them believe more in their abilities and potential. This high percentage validates what Yan (2016) claimed about one of the major actions of self-assessment which is self-directed feedback and implies that students become responsible for obtaining feedback from different sources. They even started to recognize the worth of peer-assessment and the possibility to learn from interactions with their classmates.

This excerpt in a teacher's journal reflects this new judgement towards an alternative kind of self-directed feedback:

Excerpt 1: "The peer work was useful for them to be aware of the different ways to express likes and dislikes. They started to use other expressions and to correct the use of gerunds after verbs."

Regarding teachers who participated in the pilot project, they were initially concerned about endorsing part of the assessment responsibility to their students. It is not common in our context to trust students' autonomy and skills to plan, monitor, and evaluate their learning processes. However, after three or four self-assessment sessions, the same teachers reported to have placated this concern as they noticed how students became more aware of structures, mistakes, strategies, and so on. This switch in their mindset might eventually help to spread what Panadero, Jonsson, \& Botella concluded: "A student who only follows the teacher prescription without understanding its purpose will not learn to monitor and self-adjust her work." (2017, p. 76)

Below, we can read some journal excerpts that show how teachers find the self-assessment moments useful:

Excerpt 2: "The self-assessment session was useful for most of the students to reflect on the importance to plan their presentations, rehearsing them, looking up vocabulary, practicing pronunciation, and anticipating questions."

Excerpt 3: "Students answered the questions, and they became aware of the structure and the mistakes they were making."

In the survey applied at the end of the first semester to the eleven English teachers, 100\% of them reported they noticed their students gradually showed greater understanding of their self-assessment process as seen in Figure 4. However, $9.1 \%$ felt that some students were constantly confused with the self-assessments activities themselves. These activities included the selection, use, and monitoring of specific learning strategies, questions that triggered reflection, and rubrics intended to measure their own progress. Regarding these few students, teachers added to their responses that they were usually insecure about their skills and criteria to evaluate their own work. This kind of barriers have previously been explored in other studies that have disclosed students' perspectives towards self and peer assessment. Harris \& Brown confirmed that this "mind-set that assessment is the teacher's sole responsibility remains a major challenge." (2013, p.110). In this regard, it was discussed, at the end of the first phase of the project, the importance of creating clear and accurate rubrics with the criteria of what students are expected to do in terms of their self-assessment process and how it might be reflected in their portfolios. 


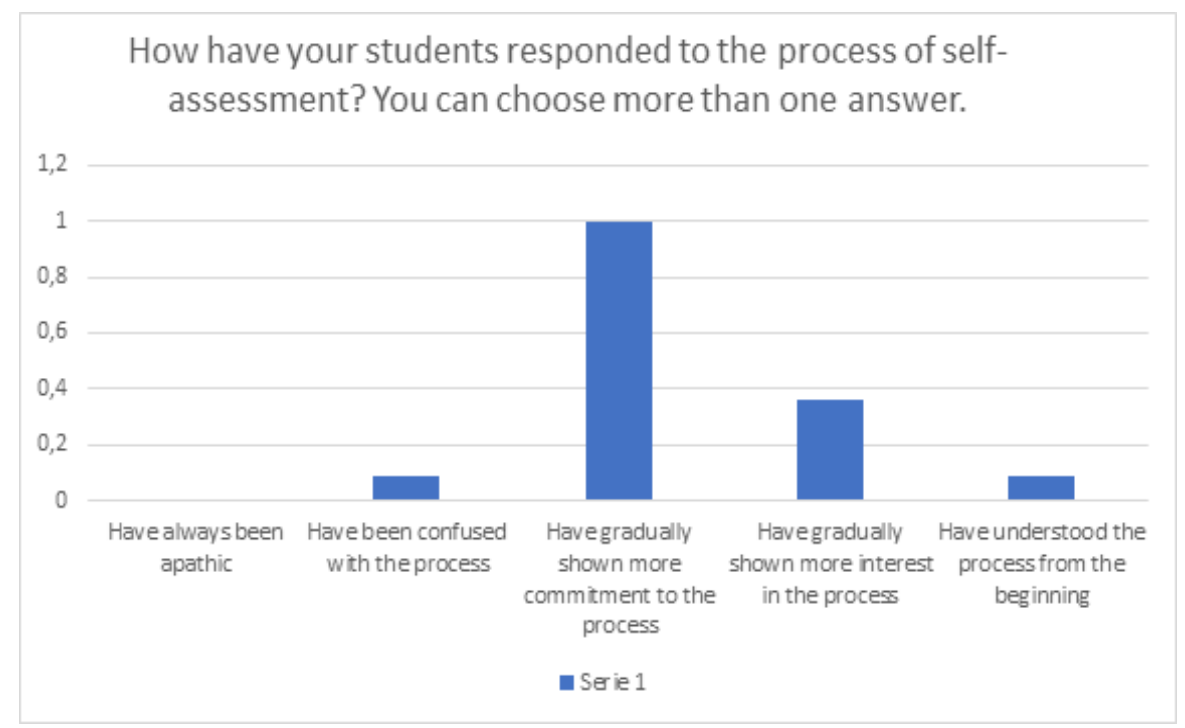

Figure 4. Teachers' perceptions on students' self-assessment process.

Another unforeseen challenge both students and teachers found on the way was the use of e-portfolios to register their use of strategies, reflections of their process, and evidence of their improvement and development of awareness. Although technology literacy among young students tends to be taken for granted, it was evidenced that their skills and interests are limited to the applications and social networks they use in their daily social life. Including a new tool where they had to store and showcase their process made $30 \%$ of the students overwhelmed because of the instructions they had to follow to collect, select, and upload the evidence of their autonomous self-assessment in an organized way. On the other hand, a surprisingly high percentage of teachers - 63\% - admitted that training students on the use of eportfolios implied an excessive load of work since they may contain complex evidence in a variety of forms - texts, pictures, recordings, videos, and so on - and the access to technology is not always guaranteed. Figure 5 summarizes these general perceptions.

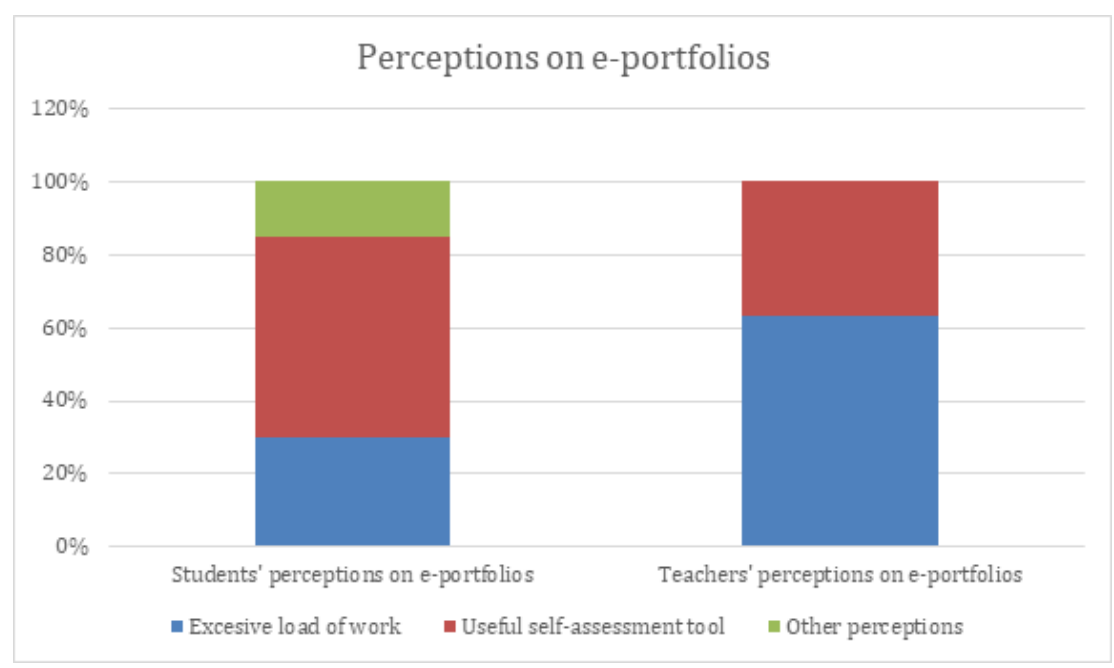

Figure 5. Students and teachers' perceptions on the use of e-portfolios.

\section{B. Task-based Learning}

On the whole, the implementation of the Task-based Learning methodology proved to be beneficial for both students and teachers at Politécnico Grancolombiano. On the one hand, the student survey results showed that $61 \%$ of the participants found tasks very meaningful and challenging since they were developed in real contexts related to their daily lives and the contents of the syllabi. On the other hand, $63.6 \%$ of the teachers surveyed claimed that TBL was one of the most beneficial aspects for the students' process. They found out that tasks were meaningful and contextualized, which helped students personalize their learning and, consequently, language acquisition became more effective and based on real learning needs. In this regard, Ellis (2003) claims that one of the main features of tasks is their authenticity, which means that they require learners to engage in language use activities such as the ones performed in the real world.

It could be seen that TBL gained acceptance, and only $8.8 \%$ of students considered that tasks were not too significant since they could be confusing, too basic, or boring. They argued that sometimes their task products were not natural and 
their speech was recited and learned by heart. As for teachers, they believe that this methodology was a good opportunity to get students more involved in their learning process, but they pointed out that it could be time consuming and it should be used along with other methodologies such as the PPP (presentation - practice - production) or other active approaches in order to guarantee the students' development of certain skills and strategies. This has also been suggested by some teachers, researchers and course designers who have implemented tasks as part of traditional approaches to make language teaching more communicative (Ellis, 2003).

Similarly, teachers' comments in the survey showed that the nature of tasks was appropriate for the development of students' skills and the increase of their motivation. Teachers acknowledged that tasks required effort and commitment, but it was a suitable way to review topics in a practical way. Teachers noticed that students became interested in the topics of the tasks, and there was positive involvement and responses thanks to the scaffolded process and the use of ICT tools that made tasks motivating and appealing. In this regard, $43.4 \%$ of students considered that the topics and the nature of tasks encouraged them to find new strategies to come up with creative and innovative products. This fact can be evidenced in teachers' comments on students' portfolios since their tasks were the result of a process in which they devoted time, and they committed to meet the task objectives even in the first course, which can be seen in figure 6 . Willis (1996) claims that students work on achieving the task outcome, and their success in completing the task is a motivating factor.

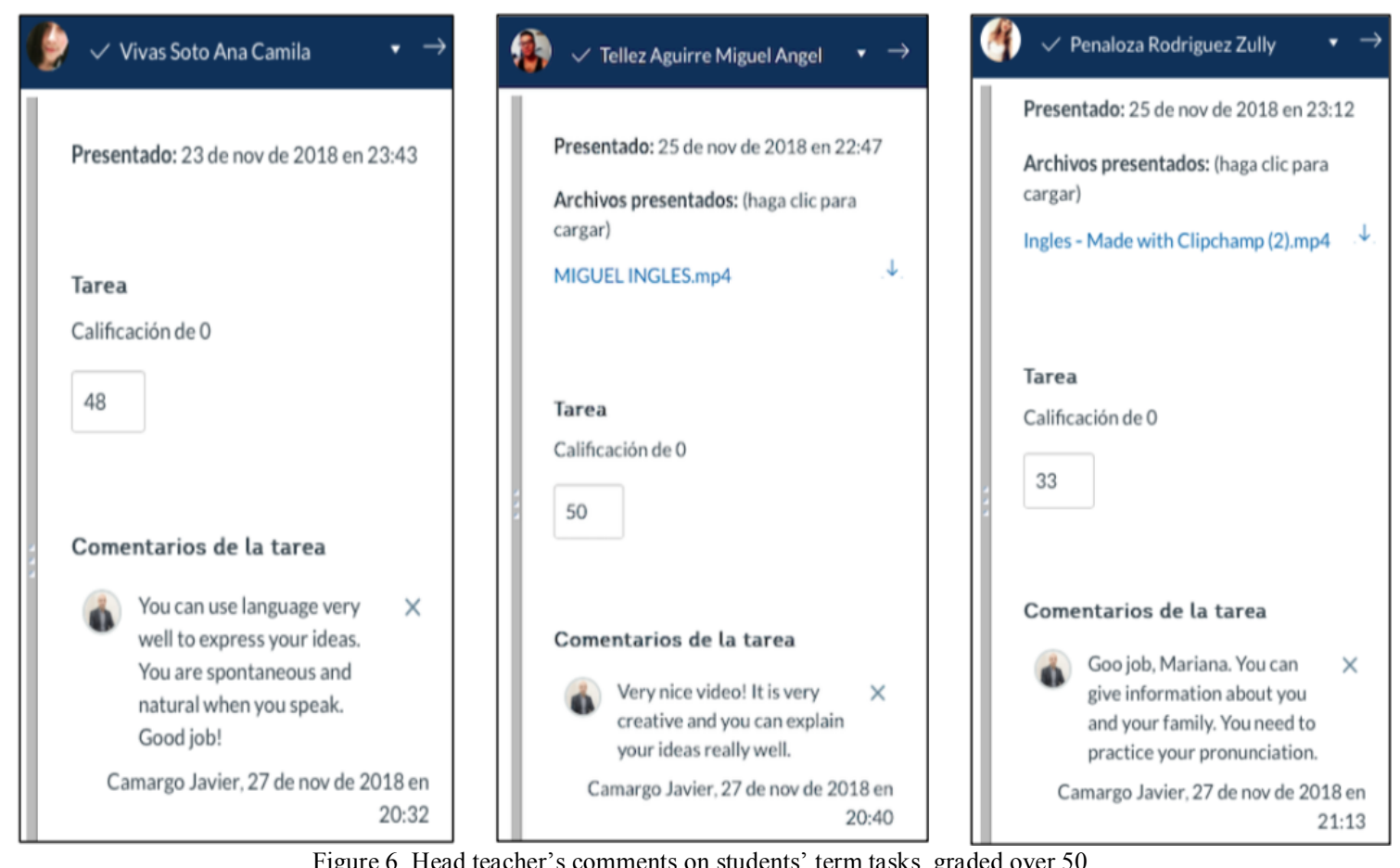

Figure 6. Head teacher's comments on students' term tasks, graded over 50.

In contrast, only $7 \%$ of the students did not feel motivated to follow the steps to develop their tasks due to the amount of extra class work they require. Some of them ensured that they had other duties with other subjects and at work, and it was difficult for them to keep up with the demands of the tasks. On the other hand, some of the teachers' comments in the survey revealed their time concerns in order to help the students understand better the objective of this methodology.

Another relevant finding in regard to the implementation of tasks is its effect on language and communication improvement. As it can be seen in figure 7, 65.4\% of students agreed that working on tasks helped them improve their language and communication skills. They pointed out that tasks were useful to review grammar topics and learn new vocabulary. In addition, students perceived that completing a task was an effective and realistic tool to keep assertive and fluent communication. As it was mentioned before, teachers claimed that it was easier for learners to acquire language by means of tasks since there are clear objectives to achieve and it allows teachers to evidence students' gradual progress with the use of language. 


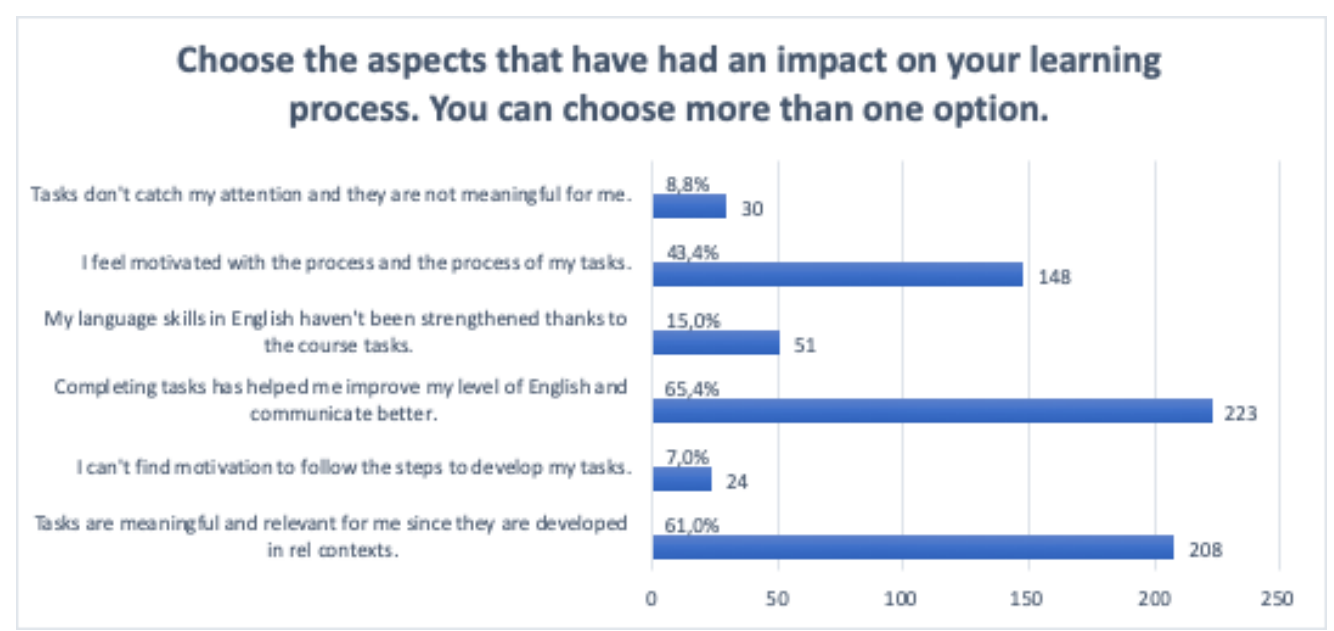

Figure 7. Students' perceptions on the impact of tasks on their learning process.

\section{Use of Technology}

As for the use of ICT in English classes, teachers were asked to plan their classes integrating some technological tools, social networks and online materials with a clear learning goal. It meant that they were asked to help their students develop TBL tasks and self-reflection practices using technology as a powerful means to reach their lesson objective (Pazó, 2008). Throughout the classes, teachers were supposed to use the institutional Learning Management System Canvas to upload their work. They shared videos, infographics and recordings done and edited by themselves and commented on one another's work. Additionally, students could use Instagram and WhatsApp to interact with their classmates and other people as preparation of some tasks. Besides, students were exposed to different PowerPoint/Prezi presentations and online material such as videos, tutorials, explanations, songs, images and interviews that provided them with real language input, which, in turn, helped them to get used to English speakers, varied sources of information as well as new ways to express ideas and receive content.

The effective implementation of the practices listed above was possible thanks to teachers' commitment and disposition. However, most of the teachers observed and expressed that although they knew they could use tools such as online games, applications, online quizzes and simulators, it was not done frequently because planning classes and developing technology based- activities took too much time and there were constant connectivity problems. In addition, a few teachers expressed that the implementation of varied ICT tools in class was not common because their use was not mandatory, they lacked some technological skills, and they could reach learning goals without technology. It is clear that for some teachers integrating technology into educational practices is a real challenge especially when they are convinced that "modern technology is simply unnecessary...a waste of time" (Alhamami \& Costello, 2019, p 600).

Although there were students that experienced feelings of frustration, boredom and fear of facing technology, there was a gradual adaptation to it. It was evident that those who were not used to using technology in their daily lives or were not good at following directions and exploring tools by themselves, struggled to learn to use websites and applications to develop routines and independence, and consequently, to do their tasks. However, despite this panorama, most of the students showed gradual interest in developing their tasks even if they implied technical problems or time to understand how they should use and make the most out of tech tools. In fact, little by little, students got used to ICT components mainly because it became a routine and these were recycled along the semester. They felt that a methodology using different websites, applications and online tools was hard and appealing though. These perceptions were also observed by teachers and systematized in their field notes, which can be evidenced in the following excerpt of teachers' journal:

Excerpt 4: "Although students showed preoccupation and fear of editing the video, they were conscious that they had to record their voice and that it was a process that implied hard work. So, they started to prepare for their task asking for help to use the online dictionaries and applications to edit videos. It was surprising especially because at the beginning of the semester they seemed to be reluctant to use technology, and they were even too lazy to do it. It appeared to be really difficult to create those habits, but it has started to change positively."

Excerpt 5: "It was evident that this time students were more familiarized with CANVAS because most of the students had checked the file uploaded there and had prepared their class. This is relevant considering that at the beginning learning to use CANVAS was a huge challenge for everybody."

As well, Figure 8 shows that teachers expressed enthusiasm for seeing the progress of their students regarding the use of CANVAS. 


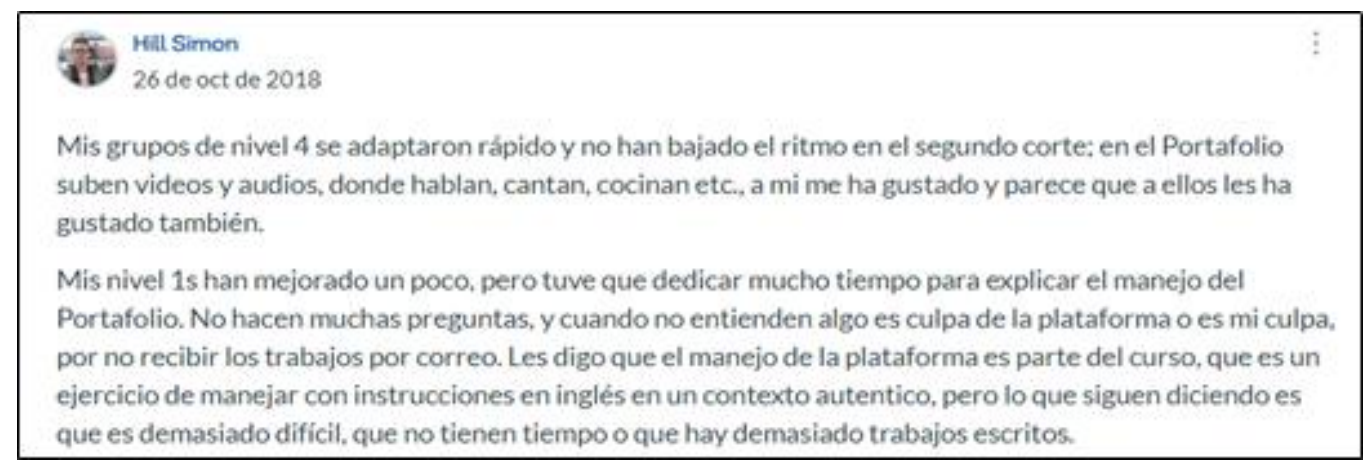

Figure 8. Teacher's perception on the implementation of ICT in class.

Regarding the advantages of implementing ICT to develop the tasks in English, it appears necessary to highlight the positive impact it had on students' feelings. Figure 9 presents the perceptions that most of students revealed by choosing interest, motivation, acceptance and satisfaction as the feelings they experienced the most. This data does not mean there were no fears or difficulties. In fact, a few students manifested to feel bored, frustrated and afraid of technology. Positively, the majority of learners acknowledged the fact that today's world requires the use of technology; that doing it in class was necessary as it was included in the syllabus, and that they felt motivated by exploring new tools to learn English. This finding was highly gratifying for them because, through the use of ICT, they could see their effort and learning when carrying out the process and seeing the final products. This is aligned to Marqués, (1996) since he asserts that having clear educational purposes with technology not only broadens opportunities to learn, but also favors students' motivation to do it.

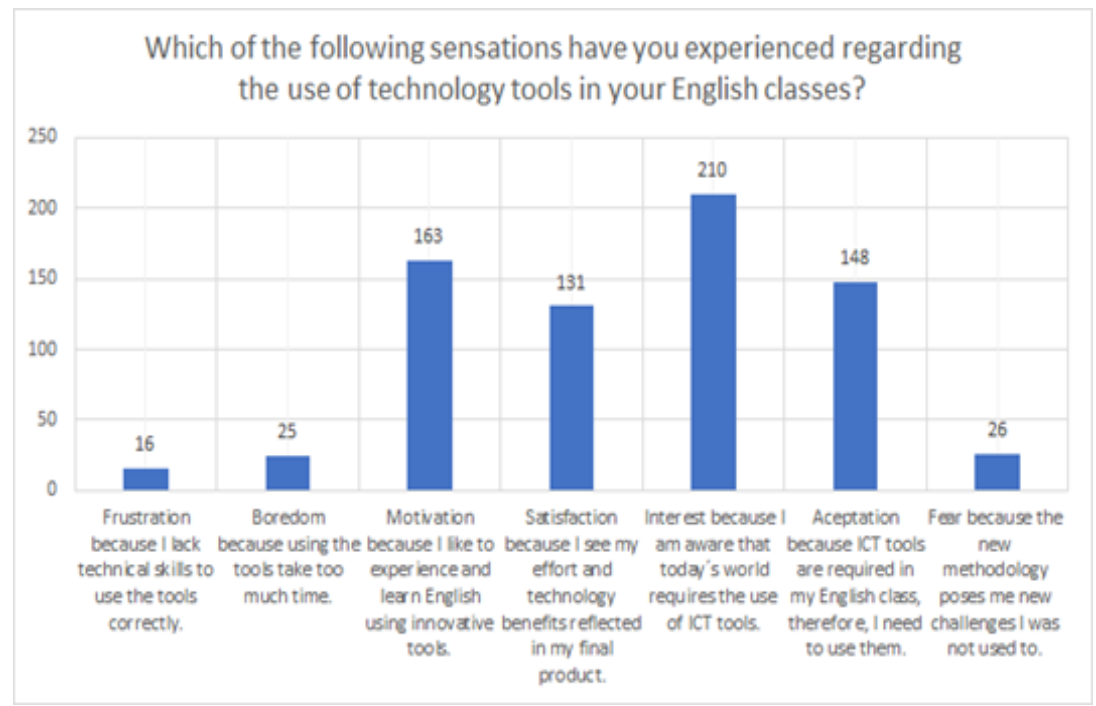

Figure 9. Students' feelings towards the use of ICT in their learning process.

Teachers and students proved that technology played the role of being more than a mere tool to exchange information (Barreto \& Iriarte, 2017). They observed that not only students came up with well-developed products and innovative ideas, but also, that they understood the process was significant because they developed new abilities; discovered different ways to carry out tasks; and were satisfactorily immersed in classes where both language input and activities were addressed through audio and video materials. Similarly, these results show that teachers could play with their imagination when planning and executing classes since their goal was to make students perceive technology as something natural and necessary. This positive experience can certainly justify the fact that, despite challenges encountered throughout the lessons implemented, a relevant percentage of teachers chose ICT as one of the most beneficial methodological tools since it made the classes more interesting, innovative and interactive, as seen in figure 10 . 


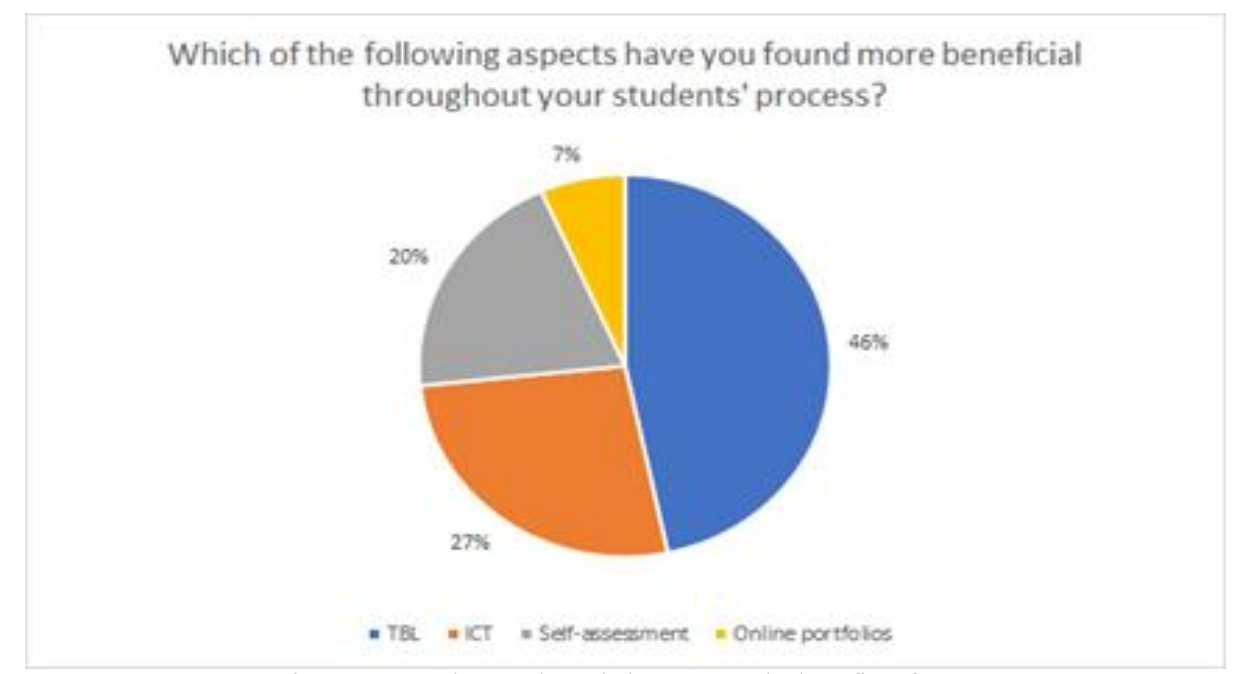

Figure 10. Teachers' acknowledgement on the benefits of ICT.

\section{CONCLUSIONS}

The acquisition of self-assessment skills in contexts where learners have not previously developed self-efficacy, learning autonomy and learning awareness is a gradual process that has to be scaffolded through constant activities intended to trigger their metacognitive thinking. This gradual, and sometimes slow, development proves to be worth the effort since self-oriented learners feel motivated, engaged and empowered in their learning process - key foundations of self-regulated and lifelong learning.

The use of tasks along with the communicative approach leads students to acquire language in a more meaningful way thanks to the realistic contexts in which they are developed. As well, students' motivation is impacted positively due to the nature of tasks since they are encouraged to be creative and resort to different kinds of tools, such as technology, to achieve the intended goal. As for teachers, the TBL approach offers a new spectrum of possibilities to make lessons more dynamic and communicative focusing essentially on meaning and helping students figure out the use of language forms. In both cases, it has been noticed that ICT plays a major role in lesson and task development.

Despite the challenges posed by the use of ICT in English classes, it was pertinent to use some of its components because they allowed students to develop tasks effectively in a creative, innovative and motivating way. Besides, it helped teachers explore new strategies to approach students' needs and skills. This implies that the integration of ICT components should be conceived as the necessary articulation of technology, clear learning objectives and purposeful activities designed to generate significant teaching and learning experiences. On the whole, it was possible to see teachers and students exploring tools, taking risks and devoting time to reach their goals, which represents a significant step in the initiation of technology-based tasks.

\section{RECOMMENDATIONS}

It is advisable to co-create rubrics; namely, involving students in their design. In this way, the evaluation criteria and what it is expected from them in the elaboration of the portfolio will be clear and meaningful. This pedagogical aspect of self-assessment has been widely addressed by other researchers. In fact, Fraile, Panadero and Pardo (2017) concluded that students who participate in the creation of these formative assessment tools internalize them in a better way, feel more engaged in the process, and may even start spontaneously to develop learning strategies.

Since TBL requires time and training, both students and teachers should gradually be coached on the concept, steps, application and evaluation of tasks. It is highly recommended that the implementation and development of tasks be scaffolded through a series of mini tasks that facilitate the achievement of objectives, providing clear instructions to guide students and avoid confusion and demotivation. Additionally, tasks should be related to students' real contexts and needs so that they become a significant part of their language acquisition process. Also, it is suggested to blend the implementation of TBL with other methodologies, in its early stages, in order to help students adapt gradually to this learning approach.

Technology with learning purposes is evidently part of the new methodology in the English courses of Politécnico Grancolombiano; and both, students and teachers, have gotten used to using ICT tools to learn English and to facing the challenges these mechanisms pose. In this regard, it is essential for teachers to keep up with the rapid changes of technology and education in order to be updated and know how to use ICT strategically. We believe that the more teachers are into technology and its wide list of resources, the more students will be immersed in innovative English learning experiences. Technology can certainly benefit these learning processes, provided that the institution not only offers the necessary technical conditions, but also the opportunities for training to take place. Besides, it should not be 
taken for granted that students know how to operate all the ICT tools, instead, they should be instructed and trained appropriately.

\section{REFERENCES}

[1] Abarca, Y. (2015). El uso de las TIC en la educación universitaria: motivación que incide en su uso y frecuencia. Revista de Lenguas Modernas, (22), 2-9. https://doi.org/10.15517/rlm.v0i22.19692.

[2] Alhamami, M., \& Costello, H. (2019). Pre-service EFL Teachers' Expectations, Needs, and Challenges in a Language Learning and Technology Course. Journal of Language Teaching and Research, 10(3), 593. https://doi.org/10.17507/jltr.1003.23.

[3] Barreto, C., \& Iriarte, F. (2017). Las TIC en educación superior: experiencias de innovación. Retrieved February 6, 2019, from http://rd.unir.net/sisi/research/resultados/15119077649789587418552 eLas TIC en la educacion superior.pdf.

[4] Bertolotti, G., \& Beseghi, M. (2016). From the learning diary to the ELP: An e-portfolio for autonomous language learning. DE GRUYTER MOUTON, 6(2), 435-441. https://doi.org/10.1515/cercles-2016-0023.

[5] Elliot, J. (1990). La Investigación-acción en Educación. Morata, S.L. Retrieved November 10, 2018, from http://www.terras.edu.ar/biblioteca/37/37ELLIOT-Jhon-Cap-1-y-5.pdf.

[6] Ellis, R. (2003). Task-based Language Learning and Teaching. Oxford: Oxford University Press.

[7] Fetterman, D. (1989). Etnography: step by step. Los Angeles, CA: Sage Publications.

[8] Fraile, J., Panadero, E., \& Pardo, R. (2017). Co-creating rubrics: The effects on self-regulated learning, self-efficacy and performance of establishing assessment criteria with students. Studies in Educational Evaluation, 53(March), 69-76. https://doi.org/10.1016/j.stueduc.2017.03.003.

[9] Harris, L. R., \& Brown, G. T. L. (2013). Opportunities and obstacles to consider when using peer- and self-assessment to improve student learning: Case studies into teachers' implementation. Teaching and Teacher Education, 36, $101-111$. https://doi.org/10.1016/j.tate.2013.07.008.

[10] Kalmbach, D \& Carr, K. (2014). Becoming a Teacher through Action Research: Process, Context, and Self-Study. New York, NY; Routledge.

[11] Lau, I. (2009). TBL in English language learning in Macau: effects on Chinese tertiary learners' beliefs and motivations (PhD Thesis). University of Nottingham. Ningbo, China.

[12] Marqués, P. (1999). El software Educativo. Retrieved February 8, 2019, from http://www.lmi.ub.es/te/any96/marques_ software/.

[13] Morchio, M. (2014). El Rol de las TIC en la clase de Inglés. Congreso Iberoamericano de Ciencia, Tecnología, Innovación y Educación, (ISBN: 978-84-7666-210-6 - Artículo 753), 11. Retrieved October 22, 2018, from https://www.google.com/search?q=Marcela+Morchio+Universidad+Nacional+de+San+Juan+sanchez.morchio\%40terredes.co m.ar\&rlz=1C1GCEU_esCO820CO820\&oq=Marcela+Morchio+Universidad+Nacional+de+San+Juan+sanchez.morchio\%40int erredes.com.ar\&aqs $=$ chrome..69i57j69i58.3.

[14] Panadero, E., Jonsson, A., \& Botella, J. (2017). Effects of self-assessment on self-regulated learning and self-efficacy: Four meta-analyses. Educational Research Review, 22, 74-98. https://doi.org/10.1016/j.edurev.2017.08.004.

[15] Pazó, M. M. S. (2008). El uso de las nuevas tecnologías en el aula de lenguas extranjeras: un cambio en el proceso de enseñanza y aprendizaje 1. Revista de Investigación y Crítica Estética, 4(ISSN: 1887-5238), 177-187. Retrieved April 7, 2019, from ampusvirtual.poligran.edu.co/\#/dash_tuto/dash_home_t.

[16] Rahmanita, M., \& Cahyono, B. Y. (2018). The Effect of Using Tumblr on the EFL Students' Ability in Writing Argumentative Essays. Journal of Language Teaching and Research, 9(5), 979. https://doi.org/10.17507/jltr.0905.11.

[17] Tang, H., Chiou, J. \& Jarsaillon, O. (2015). Efficacy of task-based learning in a Chinese EFL classroom: a case study. English Language Teaching, 8(5), 168-176.

[18] Willis, J. (1996). A Flexible Framework for Task-based Learning. Retrieved November 9, 2018, from https://s3.amazonaws.com/academia.edu.documents/50948055/PDF_A_flexible_framework_for_Task-

based_Learning_Jane_Willis.pdf?response-content-disposition=inline $\% 3 \mathrm{~B} \% 20 \mathrm{filename} \% 3 \mathrm{DA}$ _flexible_framework_for_taskbased_lear.pdf\&X-Amz-Algorithm=AWS4-HMAC-SHA256\&X-Amz-

Credential=AKIAIWOWYYGZ2Y53UL3A\%2F20190611\%2Fus-east-1\%2Fs3\%2Faws4_request\&X-Amz-

Date $=20190611 \mathrm{~T} 224305 Z \& X-A m z-E x p i r e s=3600 \& X-A m z-S i g n e d H e a d e r s=h o s t \& X-A m z-$

Signature=a199d1ba70312a1f64818f8e84409e28fb7e9ac4d9473cd0b57d6ff995371c72.

[19] Yan, Z., \& Brown, G. T. L. (2017). A cyclical self-assessment process: towards a model of how students engage in selfassessment. Assessment and Evaluation in Higher Education, 42(8). https://doi.org/10.1080/02602938.2016.1260091.

María Constanza Rodríguez is a full-time English teacher and Language Department coordinator at Politécnico Grancolombiano in Bogotá, Colombia. She holds a B. A. in Modern Languages from Universidad de Los Andes, a Specialization in translation at Universidad El Rosario, and an M. A. in Education with emphasis on EFL didactics from Universidad Externado de Colombia. She has over 20 years of teaching, materials designing and researching at a university level.

Lady Johanna Ramírez is an English teacher and International Affairs Office coordinator at Politécnico Grancolombiano in Bogotá, Colombia. She holds a B. A. in Humanities with emphasis on Spanish and English Languages from Universidad Pedagógica Nacional and an M. A. in Education with emphasis on EFL didactics from Universidad Externado de Colombia. She has over 12 years of teaching and researching at a university level. 
Mauricio Camargo Ruiz is a full-time teacher and Language Department coordinator at Politécnico Grancolombiano in Bogotá, Colombia. He is a B.A in Spanish and Foreign Languages from Universidad Pedagógica Nacional and he is currently finishing his M.A in Evaluation and Quality Assurance of Education at Universidad Externado de Colombia. He has over 15 years of experience as an EFL teacher and researcher at a university level. 